\title{
The Balance of Matrix Metalloproteinase-2 (Mmp-2) and Tissue Inhibitor of Matrix Metalloproteinase-2 (Timp-2) on Severe Endometriosis
}

\author{
Samrichard Rambulangi ${ }^{1}$, Nusratuddin Abdullah ${ }^{1}$, Irawan Yusuf ${ }^{2}$, Syahrul Rauf ${ }^{1}$ \\ ${ }^{1}$ Department of Obstetrics and Gynecology, Hasanuddin University, Makassar, Indonesia \\ ${ }^{2}$ Department of Physiology, Hasanuddin University, Makassar, Indonesia
}

Email address:

samrichard1974@yahoo.co.id (S. Rambulangi)

\section{To cite this article:}

Samrichard Rambulangi, Nusratuddin Abdullah, Irawan Yusuf, Syahrul Rauf. The Balance of Matrix Metalloproteinase-2 (Mmp-2) and Tissue Inhibitor of Matrix Metalloproteinase-2 (Timp-2) on Severe Endometriosis. Journal of Gynecology and Obstetrics. Vol. 3, No. 6, 2015, pp. 111-114. doi: 10.11648/j.jgo.20150306.12

\begin{abstract}
The objective of this study is to examine the level balance of serum and peritoneal fluid MMP-2 and TIMP-2 in patients with severe endometriosis. The method of this study was a cross sectional study with twenty patients were diagnosed as severe endometriosis based on laparoscopy and laparotomy with five controls. Serum samples were taken before surgery, peritoneal fluid samples were taken during surgery, and MMP-2 and TIMP-2 examination was conducted in the end of the study by using ELISA method. The mean level of serum, peritoneal fluid MMP-2 and TIMP-2 were compared by using unpaired t-test. Based on this study, we found that MMP-2 level of serum and peritoneal fluid was significantly different in the case compared to the control, $5.848 \pm 3.016$ vs. $1.600 \pm 0.063 \mathrm{ng} / \mathrm{mL}$ and $1.977 \pm 1.883$ vs. $0.573 \pm 0.084 \mathrm{ng} / \mathrm{mL}$ respectively. When TIMP-2 level of serum and peritoneal fluid compared to the control, the significant difference was only found in serum ( $\mathrm{p}<0.05), 0.853 \pm 0.343$ vs. $0.637 \pm 0.116 \mathrm{ng} / \mathrm{mL}$ and $1.339 \pm 2.141$ vs. $0.105 \pm 0.028 \mathrm{ng} / \mathrm{mL}$ respectively. This study showed that there was an increase of MMP-2 level of serum and peritoneal fluid and low level of serum and peritoneal TIMP-2 in severe endometriosis. Serum and peritoneal fluid MMP-2 as well as TIMP-2 in serum had a significant relationship with the incidence of severe endometriosis. Meanwhile, TIMP-2 in peritoneal fluid had no significant relationship with the incidence of severe endometriosis.
\end{abstract}

Keywords: MMP-2, TIMP-2, Severe Endometriosis

\section{Intruduction}

Endometriosis is a disease characterized by the appearance of tissue resembling endometrium outside the uterine cavity that causes chronic inflammation in the surrounding tissue. Complaints that can be felt are pelvic pain, dysmenorrhea, infertility, low back pain, dyspareunia, constipation, dysuria, and diarrhea. Dysmenorrhea and infertility are the most common complaints in endometriosis patients. However, until now, the accurate diagnosis method has not been found, except to look directly to the pelvic cavity and verify with anatomic pathology examination. [1]

The incidence rate of endometriosis is quite high in the group of infertile women ranged between $10 \%-70 \%$ and $50 \%$ in adolescent with symptom of dysmenorrhea. [2] In Jakarta, Ghazali and Hadisaputra in 2009 reported $63.6 \%$ of endometriosis incidence was infertility case. At Dr. Soetomo General Hospital Surabaya, the increased tendency was obtained in the endometriosis incidence, that was $23 \%$ in $1980,37 \%$ in 1990 , and reached $50 \%$ in 2002. [3] In Makassar, according to anatomic pathology result by Medical Faculty of Hasanuddin University for 3 years, it found 65 cases of endometriosis. [4]

MMP-2 and MMP-9 (known as gelatinase A and B) are regarded as key enzymes in the degradation of basement membrane, which are largely composed of type IV collagen. Mechanism of MMP-2 and MMP-9 actions also relies on other protease activity, which converts pro MMP-s into their active forms. Three tissue inhibitors of MMP (TIMP-1, TIMP-2, TIMP-3) regulate the protease activity. [5] TIMPs are specific endogenous enzymes involved in controlling the local activities of MMPs in tissue. TIMP-1 is specific for MMP-9 and TIMP-2 is involved in regulating MMP-2 activity. [6] 
Matrix metalloproteinase-2 (MMP-2) degrades type IV collagen and is presumed to play a role in the process of adhesion and invasion in endometriosis. MMP-2 activity occurs in two steps; a precursor of latent MMP-2 is broken by Membrane Type-1 Matrix Metalloproteinase (MT1MMP) to produce an intermediate MMP-2, and then through a catalytic process, it automatically changes MMP-2 into its active form. Unlike Matrix Metalloproteinase (MMPs) that are soluble, MT1-MMP also called Matrix Metalloproteinase-14 (MMP-14) is located on the cell surface and its increased expression activates cell surface MMP-2, a process that leads to cell invasion. [7]

In extracellular matrix, each inhibitor naturally regulates MMP activity. Tissue inhibitor of metalloproteinase- 2 has a dual role in controlling MMP-2 activity. First, TIMP2/MMP-14 complex is required to initiate pro MMP-2 activation process. On the other hand, TIMP-2 binds to the active side of MMP-2 to inhibit its activity. $[6,7]$

Chung et al. have examined mRNA expression of MMP-2, MT1-MMP, and TIMP-2 in endometriosis tissue in the endometrium of healthy women and endometriosis patients. They found that the eutopic endometrium of women with endometriosis is more invasive and likely to cause peritoneal implantation in accordance with the high expression of MMP-2 and MT1-MMP mRNA and the low expression of TIMP-2. [8] Other researchers also found an association of MMP-2 with endometriosis invasion.[7,9]

\section{Method}

This was a cross sectional study conducted from August 2014 to December 2014 in some teaching hospitals of Obstetrics and Gynecology Department of Medical Faculty of Hasanuddin University, Makassar.

The inclusion criteria were willing to follow the entire examination based on the instructions and signed the informed consent after receiving a full explanation of procedure and advantages and disadvantages of laparoscopy or laparotomy, had been given diagnosis confirmation through anamnesis, physical examination, USG, laparoscopy or laparotomy, not limited by age (menarche to menopause), and not restricted by tribe and race, not in endometriosis treatment for ovarian suppression in the last 6 months including hormonal treatment, family planning, aromatase inhibitors, and GnRH analogue. The study protocol was approved by ethics committee of Medical Faculty of Hasanuddin University, Makassar.

Twenty patients were diagnosed with severe endometriosis by laparoscopy and laparotomy action. The control was patients who were not diagnosed as endometriosis, malignancy, and pelvic infection disease, and were willing to participate in this research, and had been confirmed through anamnesis, physical, USG, laparoscopy, or laparotomy.

Five $\mathrm{mL}$ of serum samples was taken before laparoscopy and laparotomy action and $5 \mathrm{~mL}$ of peritoneal fluid samples was taken whilst performing the action. Serum and peritoneal fluid examination was carried out in Microbiology
Laboratory of UNHAS Teaching Hospital by ELISA method (Enzyme-linked immune sorbent assay). The kit used was produced by Cloud and Clone Corp., for MMP-2 SEA 100 $\mathrm{Hu}$ and TIMP-2 SEA $128 \mathrm{Hu}$. The mean level analyses of serum, peritoneal fluid MMP-2 and TIMP-2 were compared by using unpaired t-test.

\section{Result}

Twenty-five patients were included in this study. Twenty of them were diagnosed with severe endometriosis and five controls were diagnosed with no endometriosis.

Table 1 shows the characteristics of the study subjects.

Table 1. Subject characteristics.

\begin{tabular}{lll}
\hline Variable & Case $\mathbf{n}=\mathbf{2 0}$ & Control $\mathbf{n}=\mathbf{5}$ \\
\hline Age (years) mean \pm SD & $\mathbf{3 3 . 4 5} \pm \mathbf{5 . 8 2}$ & $\mathbf{4 2 . 2 0} \pm \mathbf{8 . 5 6}$ \\
\hline BMI & $17(85 \%)$ & $5(100 \%)$ \\
Normal $(18.5-25)$ & $3(15 \%)$ & $0(0 \%)$ \\
Obese $(\mathrm{BMI}>25)$ & & \\
Infertility & $12(60 \%)$ & $0(0 \%)$ \\
Primary & $1(5 \%)$ & $0(0 \%)$ \\
Secondary & $7(35 \%)$ & $5(100 \%)$ \\
Non-infertility & $14(70 \%)$ & $0(0 \%)$ \\
Parity & $6(30 \%)$ & $5(100 \%)$ \\
P0A0 & & \\
Others & $0(0 \%)$ & $2(40 \%)$ \\
Contraception & $1(5 \%)$ & $0(0 \%)$ \\
IUD & $19(95 \%)$ & $3(60 \%)$ \\
Injection (DMPA) & & \\
No Contraception & & \\
\hline
\end{tabular}

\subsection{Serum and peritoneal MMP-2}

The statistical analysis results of serum and peritoneal fluid MMP-2 are shown in Table 2. There was a significant difference between level of serum and peritoneal fluid MMP2 compared to the control $(p<0.05)$. MMP-2 level of serum in the case group showed a higher mean value than the peritoneal fluid $5.848 \pm 3.016$ vs. $1.977 \pm 1.883$.

\subsection{Serum and Peritoneal TIMP-2}

In Table 3, the statistical analysis was conducted towards serum and peritoneal fluid TIMP-2, in which there was a significant difference in serum compared to the control $(\mathrm{p}<$ 0.05). Meanwhile, the peritoneal fluid was not statistically significant compared to the control $(\mathrm{p}>0.05)$. TIMP-2 level of serum showed a lower mean than peritoneal fluid $0.853 \pm$ 0.343 vs $1.339 \pm 2.141$.

\section{Discussion}

The theory developed at this time is that endometriosis as a chronic inflammatory process with the cell function changes associated with the immunity of peritoneal environment. The peritoneal fluid of endometriosis patients experienced an increase of active macrophages which secreted various local products such as growth factors, cytokines, and tumor 
markers.[10] The increase of interleukin-6 (IL-6), IL-8, and Matrix Metalloproteinase (MMP) was associated with the implantation process of endometriosis tissue. [3]

This study aimed to examine the balance of MMP-2 and TIMP-2 towards the incidence of severe endometriosis. The arrangement of MMP-2 activity was mainly set by its own endogen inhibitor, TIMP-2, by inhibiting the MMP-2 activity and binding to its $N$-terminal domain. On the other hand, MT1MMP (MMP-14) was known to activate $72 \mathrm{kD}$ a progelatinase A after binding to TIMP-2. It was presumed that the increase of MMP-2 level in endometriosis was due to the lack of balance between MMP-2 and TIMP-2. It was because the amount of TIMP-2 receptor was not sufficient to bind the active MMP-2 in modulating angiogenesis in the development of endometriosis. [11-13]

Table 2. MMP-2 Level of Serum and Peritoneal fluid.

\begin{tabular}{llll}
\hline \multirow{2}{*}{ MMP-2 Level } & Case & Control & Independent $\mathbf{~}$ - \\
\cline { 2 - 3 } & $\mathbf{n}=\mathbf{2 0}$ & $\mathbf{n}=\mathbf{5}$ & Test (p-value) \\
\cline { 2 - 3 } & $\mathbf{M e a n} \pm \mathbf{S D}$ & $\mathbf{M e a n} \pm \mathbf{S D}$ & \\
\hline Serum & $5,848 \pm 3.016$ & $1,600 \pm 0,063$ & 0,000 \\
Peritoneal fluid & $1,977 \pm 1,883$ & $0,573 \pm 0,084$ & 0,004 \\
\hline
\end{tabular}

Table 3. TIMP-2 Level of Serum and Peritoneal fluid.

\begin{tabular}{|c|c|c|c|}
\hline \multirow{3}{*}{ TIMP-2 Level } & Case & Control & \multirow{3}{*}{$\begin{array}{l}\text { Independent T- } \\
\text { Test (p-value) }\end{array}$} \\
\hline & $\mathrm{n}=\mathbf{2 0}$ & $\mathrm{n}=5$ & \\
\hline & Mean \pm SD & Mean \pm SD & \\
\hline Serum & $0,853 \pm 0,343$ & $0,637 \pm 0,116$ & 0,030 \\
\hline Peritoneal fluid & $1,339 \pm 2,141$ & $0,105 \pm 0,028$ & 0,217 \\
\hline
\end{tabular}

This study obtained an increase of MMP-2 in serum and peritoneal fluid. It was in line with Huang et al. that found the elevated level of MMP-2 in serum and peritoneal. Some studies indicated excessive expression of MMP-2 in patients with endometriosis. [14] MMP-2 concentration was positively correlated with estrogen level, implying that estrogen had an up-regulatory effect on the production of MMP-2 in patients with endometriosis. [15] Ectopic endometrial tissue was able to secrete estradiol (E2) and also prostaglandin E2 (PGE2), an inflammatory agent which triggered macrophages such as monocyte chemotactic protein 1 (MCP-1), neurotropic peptide such as nerve growth factor (NGF), enzymes that formed tissue, i.e. matrix metalloproteinase (MMP), and tissue inhibitor of MMP (TIMP). [14]

The low level of TIMP-2 in serum and peritoneal fluid was presumed to be caused by the insufficient amount of TIMP-2 receptor to bind the active MMP-2 in modulating angiogenesis in the development of endometriosis. [11,14] Huang et al. also found that TIMP-2 concentration of serum and peritoneal fluid was lower in endometriosis. [14] In Table 3, it seemed that serum and peritoneal fluid TIMP-2 were higher in the case compared to the control. It showed that TIMP-2 actually responded to the high level of MMP-2, but the mechanism of why TIMP-2 receptor did not have a sufficient amount was not clear yet.

\section{Conclusion}

Serum and peritoneal fluid MMP-2 as well as TIMP-2 in serum had a significant relationship with the incidence of severe endometriosis. Meanwhile, TIMP-2 in peritoneal fluid had no significant relationship with the incidence of severe endometriosis. Serum MMP-2 can be used to diagnose severe endometriosis but it should consider other influencing factors.

\section{References}

[1] Situmorang H, Mutia K. Endometriosis. In: Hestiantoro A, Natadisastra RM, Sumapraja K, Wiweko B, Pratama G, Situmorang $\mathrm{H}$, et al., editors. Best Practice on IMPERIAL. 1 ed. Jakarta: CV Sagung Seto; 2012. p. 65-76.

[2] Annas JY. Perbandingan Ekspresi Prostaglandin E2 (PGE2), Matrix Metalloproteinase 9 (MMP-9) dan Luas implan lesi Endometriosis akibat pemberian Kurkumin dosis $240 \mathrm{mg} / \mathrm{Kg}$ $\mathrm{BB}, 500 \mathrm{mg} / \mathrm{KgBB}$ dan $1000 / \mathrm{Kg}$ BB pada mencit model Endometriosis. [Laporan Penelitian]. Surabaya: UNAIR; 2013.

[3] Hadisaputra W. Kombinasi Petanda Biologis (IL-6, TNF- $\alpha$, MMP-2, VEGF) dan gejala serta tanda klinis sebagai model prediktor diagnosis endometriosis perempuan masa reproduksi [Disertasi]. Jakarta: Universitas Indonesia, Jakarta; 2012.

[4] Irfan, Rambulangi J, Bandaso R. Tinjauan kasus Endometriosis di bagian patologi anatomi fakutas kedokteran Unhas. Fakultas Kedokteran Universitas Hasanuddin, 2010.

[5] Naruse K, Lash GE, Innes BA, Otun HA, Searle RF, Robson $\mathrm{SC}$, et al. Localization of matrix metalloproteinase (MMP-2), MMP-9 ang tissue inhibitors for MMPs (TIMPs) in uterine natural killer cells in early human pregnancy. Human Reproduction. 2009; 24(3): 553-61.

[6] Aresu L, Benali S, Giannuzzi D, Mantovani R, Castagnaro M, Falomo ME. The role of inflammation and matrix metalloproteinases in equine endometriosis. Veterinary Science. 2012; 13(2): 171-77.

[7] Londero AP, Calcagno A, Grassi T, Marzinotto S, Orsaria M, Beltrami CA, et al. Survivin, MMP-2, MT1-MMP, and TIMP2: their impact on survival, implantation, and proliferation of endometriotic tissues. Virchows Arch. 2012; 461: 589-99.

[8] Artini, P., Ruggiero, M., Papini, F., Simi, G., Cela, V. \& Genazzani, A. 2012. Endometrisis and angiogenic factors. In: Chaudhury, K. (ed.) Endometriosis-Basic concepts and Current Research Trends. First ed. Rijeka, Croatia: InTech Europe.

[9] Jana, S., Rudra, D. S., Paul, S. \& Swarnakar, S. 2012. Curcumin delays endometriosis development by inhibiting MMP-2 activity. Indian Journal of Biochemistry and Biophysics, 49, 342-348.

[10] Speroff L, Fritz A. Endometriosis. Clinical Gynecologic Endocrinology and Fertility. Eight ed. Philadelphia: Lippincott Williams and Wilkins 2011. p. 1221-48.

[11] Jana S, Rudra DS, Paul S, Swarnakar S. Curcumin delays endometriosis development by inhibiting MMP-2 activity. Indian Journal of Biochemistry and Biophysics. 2012; 49: $342-8$. 
[12] Bozzuto G, Ruggieri P, Molinari A. Molecular aspect s of tumor cell migration and invasion. Ann Ist Super Sanita. 2010; 46(1): 66-80.

[13] Li, S., Shen, X., Yang, Z., Wu, A., Tang, Z., Li, M. \& Li, Y. 2014. Clinical significance of MMP-2 overexpression in endometrial adenocarcinoma. Nan Fang Yi Ke Da Xue Xue Bao, 34, 423-5.

[14] Weigel, M. T., Kramer, J., Wenners, A., Alkatout, I., Jonat, W.,
Maass, N. \& Mundhenke, C. 2012. Differential expression of MMP-2, MMP-9 and PCNA in endometriosis and endometrial carcinoma. European Journal of Obstetrics \& Gynecology and Reproductive Biology, 160, 74-8.

[15] Londero, A. P., Calcagno, A., Grassi, T., Marzinotto, S., Orsaria, M., Beltrami, C. A., Marchesoni, D. \& Mariuzzi, L. 2012. Survivin, MMP-2, MT1-MMP, and TIMP-2: their impact on survival, implantation, and proliferation of endometriotic tissues. Virchows Arch, 461, 589-99. 